\title{
Skeletal Metastatic Carcinomas from the Roman Period (1st to 5th Century AD) in Hungary
}

\author{
Mónika Merczi ${ }^{a}$ Antónia Marcsik ${ }^{b}$ Zsolt Bernert ${ }^{c}$ László Józsa ${ }^{e}$ \\ Krisztina Buczkó $^{d}$ Gábor Lassányi ${ }^{f}$ Márta H. Kelemen ${ }^{a}$ Péter Zádori ${ }^{\text {h }}$ \\ Csaba Vandulek $^{\mathrm{h}}$ Gergely Biróh $^{\mathrm{h}}$ Tamás Hajdu $^{\mathrm{g}}$ Erika Molnár ${ }^{\mathrm{b}}$ \\ ${ }^{a}$ Department of Archeology, Balassa Bálint Museum, Esztergom, ${ }^{b}$ Department of Biological Anthropology, \\ University of Szeged, Szeged, Departments of ${ }^{\mathrm{C}}$ Anthropology and ${ }^{\mathrm{d}}$ Botany, Hungarian Natural History Museum, \\ e Department of Pathology, National Institute of Traumatology, ${ }^{\mathrm{f} D e p a r t m e n t}$ of Roman Archeology, Aquincum \\ Museum, Budapest History Museum and 9 Institute of Biology, Department of Biological Anthropology, Eötvös \\ Loránd University, Budapest, and ${ }^{\mathrm{h}}$ Health Center, Kaposvár University, Kaposvár, Hungary
}

\section{Key Words}

Historical anthropology · Paleopathology · Skeletal metastasis · Roman period · Hungary · Scanning electron microscopy $\cdot$ Computed tomography

\begin{abstract}
Objectives: According to paleopathological records, tumors have a great antiquity. The prevalence of cancer in ancient populations might have differed from that in modern humans because of substantial differences in environmental factors, life expectancy and the availability of treatment. This study presents 3 cases of probable skeletal metastatic carcinoma from the Roman period ( 1 st-5th century AD) in Hungary, showing the development of bone metastases of cancer without chemo- and radiotherapy. Methods: All skeletons were subjected to a careful macroscopic investigation, which was extended by radiological, stereo- and scanning electron microscopic analyses. Results: In 1 case, the mixed nature and localization of the lesions, as well as the sex and age of the individual, suggested breast cancer as the primary focus. In the other 2 cases, based on the mostly osteoblastic nature and the localization of the lesions as well as on the
\end{abstract}

sex and age of the individuals, the most probable diagnostic option is prostate carcinoma with skeletal metastases. Conclusions: In view of the scarcity of cancer metastases that have been diagnosed in archeological specimens in general, identification of all examples of cancer in antiquity represents an important contribution both to paleopathology and to modern medicine.

(c) 2014 S. Karger AG, Basel

\section{Introduction}

Cancer is one of the leading causes of death worldwide today. Tumors, however, are not simply diseases of recent advanced societies but had also been a threat to health in much earlier populations. According to paleopathological records, tumors have a great antiquity [1]. Both benign and malignant tumors have been known to occur since the Neolithic [2,3]. The prevalence of cancer in ancient populations might have differed from that in modern humans because of substantial differences in environmental factors (such as tobacco, certain drugs, pollution and diet), life expectancy and the availability of treatment $[4,5]$. 
Paleooncology - as a part of paleopathology - is a new term established by Halperin [4], and it refers to the study of malignant tumors in ancient human populations and in their hominid ancestors. These populations provide information of crucial importance concerning the possible influences of morphological and functional evolution, diet, lifestyle and other environmental factors on tumorous diseases. This new discipline may have a deep impact on our knowledge of the natural history of cancer. The application of improved diagnostic techniques - such as paleohistology, micro-computed tomography (microCT) or proteomic analysis - [6-8] may enable paleooncology to contribute to a large extent to our understanding of cancer.

Several cases of bone tumor have been reported from historical anthropological materials. However, the majority of paleooncological studies only deal with case histories without paleoepidemiological reconstruction of these conditions [9-15]. The analysis of tumor frequencies in populations from different historical periods may reveal the role of environmental factors in carcinogenesis. Only few reports exist that describe human remains with traces of malignant tumors in historical populations of different times and locations [16-22].

In Hungary up-to-date evidence of primary or metastatic malignant bone tumors from ancient times was identified in 24 cases. Osteosarcoma was diagnosed only in 4 cases $[9,23,24]$, which is not surprising, because the occurrence of osteosarcoma is relatively rare in recent communities too. In a further 4 cases, multiple myeloma $[10,13,25,26]$ was diagnosed. However, the presence of bone metastases was recognized in 17 cases $[10,13,24,27-32]$. Regarding the type of metastatic alterations, the predominance of osteolytic lesions has to be mentioned. The observed cases belonged mostly to older age categories, which fact correlates with the generally accepted view that cancer is primarily a disease of old age. In spite of that, according to the Hungarian historical material, only young adults were affected by osteosarcoma. According to modern medical data, based on autopsies of more than 1,000 cancer patients, only $10 \%$ of the individuals had bone metastasis [33]. Consequently, the 17 skeletal metastatic carcinomas detected suggest that the number of primary malignant tumors could be much higher in the Hungarian historical material.

The aim of our study was to present 3 cases of probable skeletal metastatic carcinoma from the Roman-period settlements of Aquincum (Graphisoft $1287=$ G 1287) and Solva [Esztergom-Bánom Hill (Esztergom Bánomi dűlő)
262 and $284 \mathrm{~A}=\mathrm{EB} 262$ and EB 284A] in Hungary. These historical cases represent the development of bone metastases of cancer without chemo- and radiotherapy based on macroscopic, radiological and scanning electron microscopic (SEM) studies.

\section{Archeological Background}

The western part of Hungary belonged to Pannonia (Roman military province) from the first half of the 1st century for about 400 years. Along its frontier, formed by the Danube River, a chain of military camps and watchtowers was erected. In the inner part of the province, beside the settlements of the native population, towns were founded. At the beginning of the 2 nd century, the province was divided into two, and at the end of the $3 \mathrm{rd} /$ beginning of the 4th century into four parts [34].

Aquincum, one of the most important Pannonian settlements, was the center of Pannonia Inferior in the 2nd and 3 rd centuries. The Roman civil town and the military camp of Aquincum, however, were founded in the second half of the 1 st century. The large eastern cemetery of the civil town is situated on the sand knolls along the bank of the Danube. Systematic scientific investigations of the cemetery could be launched from 1996 in the course of Paula Zsidi's excavations in connection with the construction of the Graphisoft industrial park. In 1998 and 2000 nearly 50 Roman graves were uncovered [35]. However, the real size and importance of the eastern cemetery only became apparent during the course of investigations conducted nearly each year from 2005 until now (2013): more than 1,300 Roman-period burials were uncovered on territories that were less disturbed by modern industrial establishments $[36,37]$. The analysis of the rich material found has not yet been finished.

Esztergom, the Roman Solva, was already an important element of the Pannonian frontier in the early period of the Roman Empire. The military camp of Solva was built under Emperor Claudius (40-54 AD) and remained in use until around 430-440 AD [34]. The cemetery of the fort was established on the western and eastern slopes of Bánom Hill. The 335 graves which were excavated in 1986-1990 by M.H.K. on the eastern slope of the hill, in Bánom Lane, formed a separate part within the late Roman cemetery. This part of the cemetery was opened in the first half of the 4th century, approximately between $331 \mathrm{AD}$ and $350 \mathrm{AD}$, and it was continuously used in the first half of the 5th century too. In the cemetery, only inhumation was practiced [38]. 


\section{Materials and Methods}

From the long-running excavation of the Graphisoft cemetery, the skeletal remains of 605 individuals were uncovered. The anthropological and paleopathological investigations were carried out using standard methods [39-43] by Z.B. at the Department of Anthropology of the Hungarian Natural History Museum, Budapest, where the skeletons are housed. The age-atdeath distribution of the skeletons is the following: 125 subadults and 480 adults (226 males, 231 females and 23 individuals of undeterminable sex). The maximum of mortality for the females was at the age of 25-29 years, and for the males at the age of $40-45$ years.

Our first case (G 1287) comes from this cemetery. The skeletal remains of the individual were demolished by a concrete wall. The upper part of the inhumation grave was destroyed, the lower limb bones were also found in disturbed position. No grave goods were documented for the burial site. The data from the neighboring graves are rather late (late 3 rd century to 4 th century AD). Apart from this case, no other skeletal remains with metastases were detected in the Graphisoft series. The most common pathological changes were degenerative lesions of the spine. This is not surprising, since these alterations are among the most common lesions observed in archeological human remains.

From the 335 graves of the Esztergom-Bánom Hill cemetery, the skeletal remains of 408 individuals could be separated. The anthropological and paleopathological analyses of the skeletons were performed by M.M. using standard methods [39-43]. The osteological remains are housed in Esztergom, in the anthropological collection of the Balassa Bálint Museum. In the cemetery, the number of subadults is 110 . Among the adult population, the sex ratio is uneven: the number of males $(n=161)$ is higher than that of females $(n=132)$. Most of the males died between the ages of 45 and 49 years, most of the females at the age of 35-39 years [44].

Our second and third cases of probable skeletal metastatic carcinoma are linked to this cemetery. On the basis of the grave goods (glass bottle and coin), the skeletal remains of EB 262 can be dated back to the middle or the second half of the 4th century. According to clay and glass bottles, EB 284A can be dated back to the 5th century. This specimen was buried together with 2 subadults (915 months and 10-14 years old) in a stone box grave sufficient for the burial of only one person. Therefore, these 3 individuals could not have been buried at the same time.

Besides skeletal metastatic lesions, the analysis of the anthropological material revealed several other pathological cases. Among them the large number of traumatic lesions is worth mentioning [45]. The 3 suspected skeletal metastatic carcinoma cases were subjected to careful macroscopic investigation, which was extended by radiological examination and by stereomicroscopic and SEM analysis.

CT examinations were performed using a Siemens Sensation 16 Multislice Spiral CT device. Bone window axial images were obtained with $1 \mathrm{~mm}$ slice thickness. Based on the primary data and axial CT images, secondary multiplanar reconstructions (MPR) and volume rendering technique (VRT) reconstructions were performed for better visualization. Electron microscopy coating with gold/palladium was accomplished for scanning using a SC7620 Mini Sputter Coater for $120 \mathrm{~s}$ at $16 \mathrm{~mA}$. A Hitachi S-2600N scanning electron microscope operated at $20 \mathrm{kV}$, and a 5- to $8-\mathrm{mm}$ distance was used.

\section{Results}

\section{Case 1: $G 1287$}

The skeleton of this individual is very poorly preserved and incomplete. Only fragmented parts of the hip bones, the sacrum, both femora, the right radius and the left ulna are available for study (online suppl. fig. 1; for all online suppl. material, see www.karger.com/ doi/10.1159/000357435). The age at death was determined as over 45 years by the morphological examination. Its sex was difficult to determine as many features were morphologically undefined; however, the skeleton was finally assessed as probably male.

\section{Macroscopy and Radiology of Pathological Changes}

The distribution of pathological alterations is shown in online supplementary figure 1. There is evidence of new bone formation on the pelvis. Widespread deposits are present on the pelvic bones, and both medial and lateral surfaces are involved. The left innominate bone displays heterogeneous pathological lesions (fig. 1a). Multiple, clearly defined, fine porous outgrowths, varying in size $(2-8 \mathrm{~mm})$, can be seen in the vicinity of the greater sciatic notch (fig. 1b). As well as new bone formations, the porous appearance of the cortical layer is also characteristic. The region damaged post mortem next to the spina iliaca posterior exhibits thin porous plaques of new bone (fig. 1c).

Similar porous new bone with a slightly striated appearance is widespread on both surfaces of the right innominate bone. The superior portion of the iliac wing shows multiple areas of uneven and roughened abnormal bone and holes of different sizes (1-1.5 mm). The external aspect of the right ilium near to the iliac crest displays spiculated new bone as well as nodular osseous outgrowth (online suppl. fig. 2a, b). Due to postmortem breakage, pathological changes are visible in the spongy bone too. The original bone had been completely replaced by sclerotic new bone (fig. 1d). Although the sacrum is seriously damaged (online suppl. fig. 3a), the second sacral ver-

Fig. 1. Pathological changes of skeleton G 1287. a-c Left innominate bone. Fine porous lesions of various size on the medial $(\mathbf{a}, \mathbf{b})$ and lateral surfaces (c). d Complete obliteration of the original spongy bone (right iliac bone). e Completely rebuilt inner structure of the left femur. $\mathbf{f}, \mathbf{g}$ VRT CT reconstructions of the iliac bone showing diffuse sclerotic lesions. h Irregular network of newly built sclerotic trabeculae (1) between remnants of the original trabeculae (arrow). SEM image of the sacrum. i Detailed view of the surface of a spongiotic trabecula showing Howship's lacunae. SEM image of the left femur.

(For figure see next page.) 


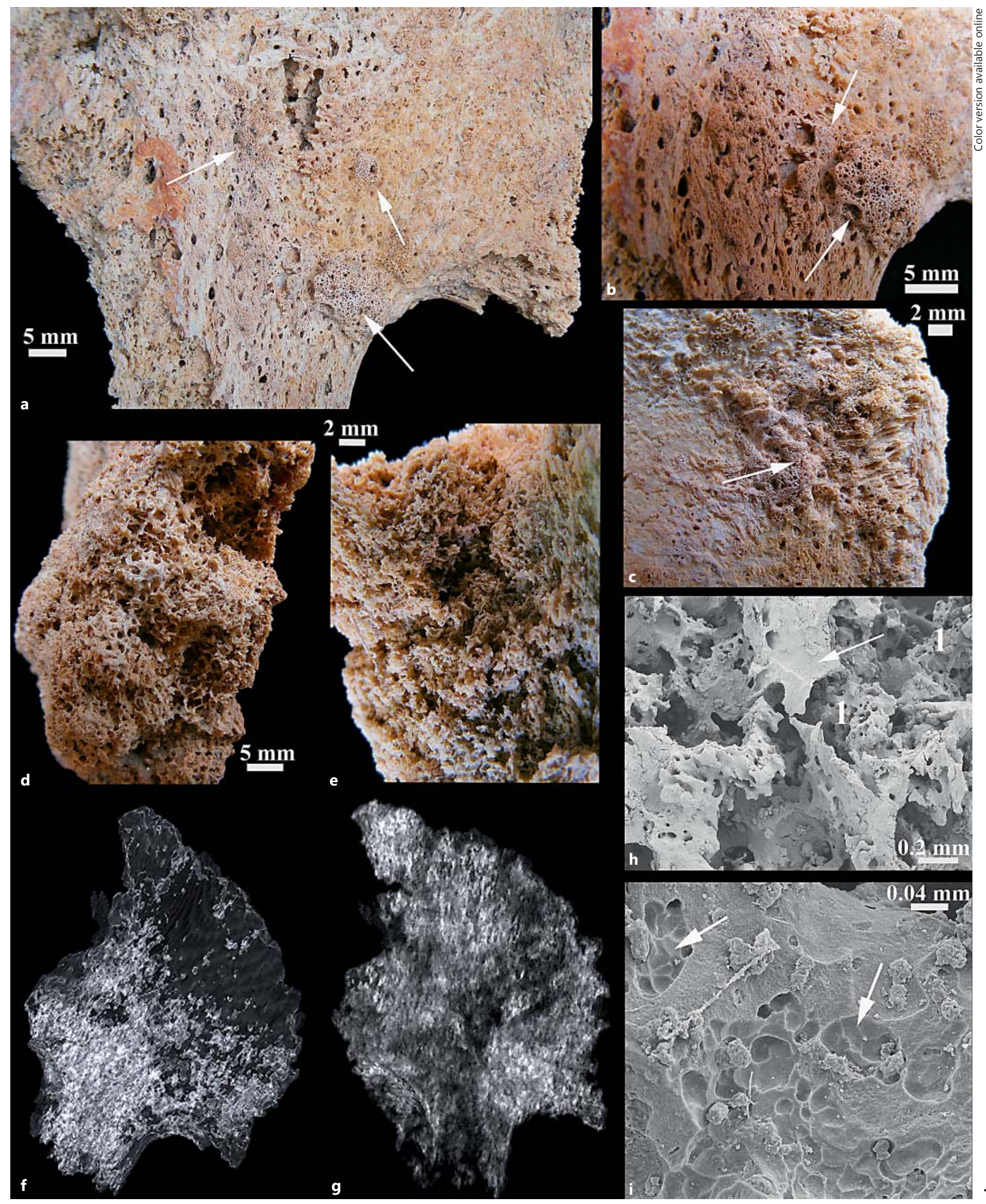


tebra reveals similar sclerotic alterations (online suppl. fig. 3b).

On both femora, near to the lesser trochanter, the porous nature of the cortical surface can be seen, alongside with a slight periosteal apposition on the left side. The inner structure of the left femur is completely rebuilt, exhibiting sclerotic areas (fig. 1e; online suppl. fig. 3c). The obtained axial CT images and the secondary reconstructions of the examined bones represent severe pathological changes: multiple sclerotic lesions and periosteal appositions. The VRT CT reconstructions of the iliac bone show diffuse sclerotic lesions (fig. 1f, g).

\section{Scanning Electron Microscopy}

Samples for the SEM examinations were taken from the sclerotic part of the second sacral vertebra and from the femur. In spite of postmortem damage, the foci of pathologically changed trabeculae are well delimited and can be recognized. Although most lesions are blastic, lytic changes are also present.

The SEM pictures of the sacral sample show loss of normal spongy bone structure. Between the remnants of the original trabeculae, an irregular network of newly built sclerotic trabeculae can be detected (fig. 1h). Under higher magnification, the trabecular surface in the femoral sample is well visible. The entire surface of a spongy trabecula is covered by a vast amount of lacunae of different dimensions, suggesting a lytic process. The spongiotic trabeculae show massive destruction and lacunae originally occupied by the osteoclasts (and/or tumorous giant cells; fig. 1i; online suppl. fig. 3d).

\section{Case 2: EB 262}

The robust skeleton EB 262 showed destruction of the skull, scapulae, ribs, spine and pelvis. Most of the long bones available are incomplete and fragmentary. The skull and the spine are the best-preserved elements (online suppl. fig. 4). According to the ossification of the cranial suturae and the changes in the inner structure of the femur, the age at death can be estimated at 40-49 years. The sexual traits of this individual are masculine. The skeleton shows multiple pathological lesions at a number of sites (online suppl. fig. 4).

\section{Macroscopy and Radiology of Pathological Changes}

There is a localized fine porosity on the skull $(31 \times 19$ $\mathrm{mm}$ ) manifesting along the coronal suture on the endocranial surface of the right frontal and parietal bones. The ectocranial surface of the right parietal bone anterior to the obelion reveals a markedly rounded porous area (di- ameter: $31 \mathrm{~mm}$; fig. $2 \mathrm{a}$; online suppl. fig. $5 \mathrm{a}$ ). The endocranial plate associated with this lesion exhibits a thin layer of porous new bone. There is a discrete, rounded (diameter: $10 \mathrm{~mm}$ ) porous area on the ectocranial surface of the left parietal bone near the parietal eminence. The porosity of the associated endocranial area is more pronounced and a poorly organized new bone is also apparent in this region. Next to the right occipital condyle, the ectocranial surface displays a very porotic area $(14 \times$ $23 \mathrm{~mm}$ ). There is a similar, but less advanced, lesion on the associated endocranial surface.

The postcranial lesions in this specimen appear to be more variable morphologically than those of the skull, although the picture is complicated by postmortem breakage. All the vertebrae exhibit a porotic appearance (online suppl. fig. 5f). More pronounced osteolytic lesions are visible on the vertebral arch of the cervical (fig. 2b) and thoracic vertebrae. As well as porosity there are also some proliferative lesions: the vertebral arch of the lumbar vertebrae reveals a thin layer of new bone formations. In addition, the thoracic vertebrae display osteoblastic lesions around the costal facets. Due to the fragmentary nature of the 1 st and 2 nd lumbar vertebrae, the inner structure of the corpus is visible. Both vertebrae display new, irregular bone growth with almost complete obliteration of the original spongy bone. In the upper ribs, the predominant pathological changes are multiple lytic lesions perforating the cortical bone. Besides porosity, the lower ribs are also affected by proliferative lesions, and they are located very close to the lytic lesions (fig. 2c). One of the lower ribs exhibits a massive spiculated new bone layer (fig. 2e; online suppl. fig. 5b). Both scapulae exhibit multiple fine, discrete lytic lesions that are distributed throughout the cortex of the scapular elements available, except for the articular surfaces. There is irregular, proliferative woven bone in some areas, more marked on the left than the right scapula (fig. 2 f; online suppl. fig. $5 \mathrm{c}-\mathrm{e}$ ).

Fig. 2. Pathological changes of skeleton EB 262. a Ectocranial surface of the right parietal bone revealing a marked rounded porous area. b Pronounced osteolytic lesions on the vertebral arch of cervical vertebrae. c Proliferative lesions closely related to the lytic lesions of a rib. d VRT CT reconstructions of the rib revealing diffuse osteoblastic changes, sclerotic lesions and periosteal appositions. e Massive spiculated new bone layer of a rib. Arrows: border of the original cortical surface. $f$ Irregular, proliferative woven bone of the left scapula (dorsal surface). g Coarse, proliferative bone formations and lytic alterations of the left iliac bone (lateral surface). $\mathbf{h}$ Fine trabecular new bone filling the spaces (left femur). i SEM image of a rib exhibiting the replacement of normal trabecular bone by irregularly structured new bone. Arrow: remnant of destroyed original trabeculae.
Merczi et al. 


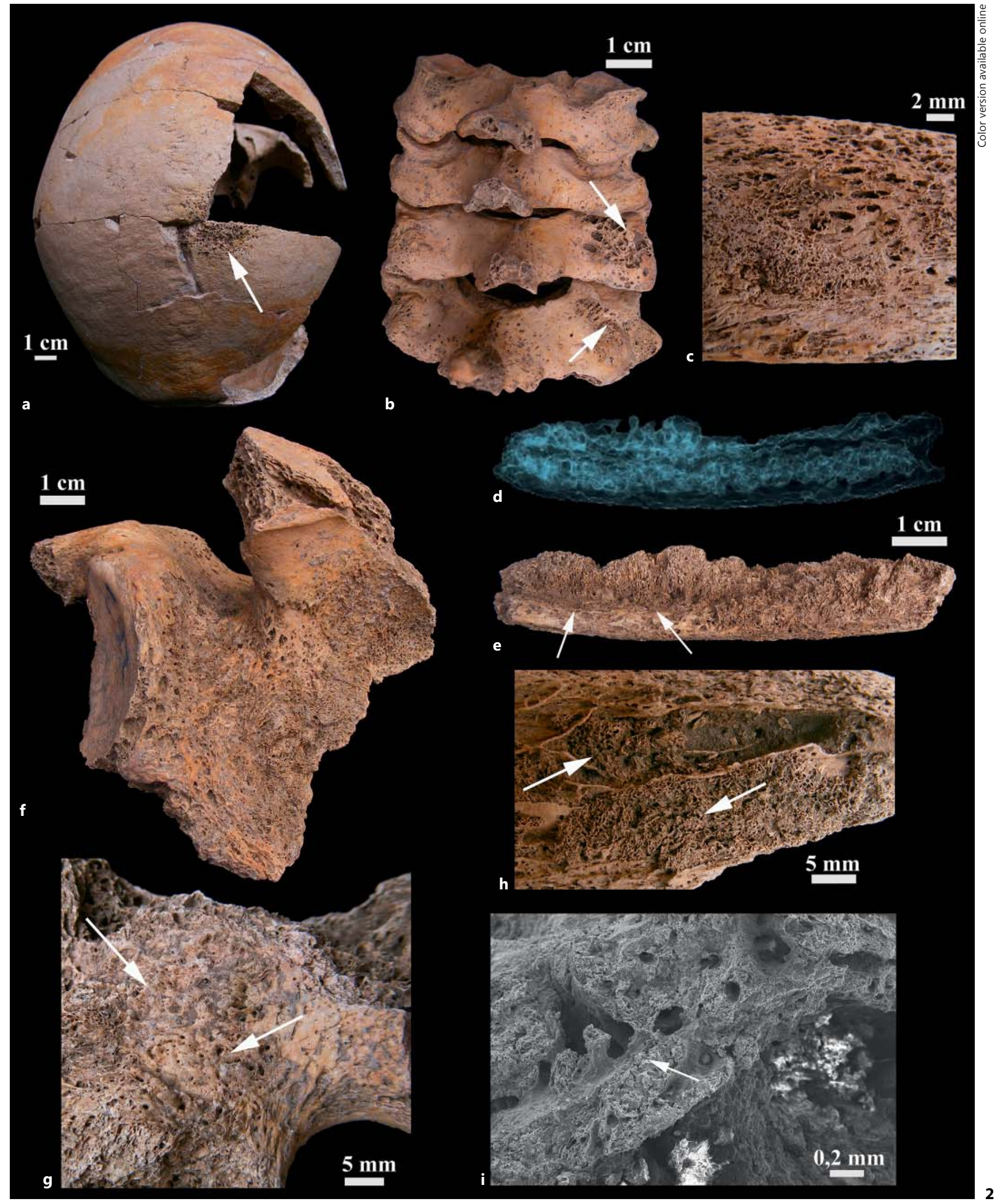


The sternal ends of both clavicles reveal periosteal apposition. Similarly to the ribs, the fragmented hip bones have pathological lesions that consist of multiple widespread osteolytic cortical lesions, in some cases associated with coarse, proliferative bone formations (fig. 2g; online suppl. fig. $6 a, b)$. Near the acetabuli, the external cortical surface is irregular, exhibiting fine, porous, nodular new bone formations. There is a slight porous periosteal apposition along the diaphysis of the left femur (online suppl. fig. 6c, d). Inside the femoral neck and both trochanters, fine trabecular new bone can be seen filling the spaces between trabeculae (fig. $2 \mathrm{~h}$ ).

The radiological pictures of the examined bones show diffuse osteoblastic changes, multiple sclerotic lesions and periosteal appositions. The presented VRT CT reconstructions of the rib clearly reveal the abovementioned diffuse osteoblastic changes, sclerotic lesions and periosteal appositions (fig. 2d; online suppl. fig. 6e-h).

\section{Scanning electron microscopy}

Some of the bones were observed under a scanning electron microscope. Samples were taken from a left rib and from the right scapula. The spongy bone of the rib is completely rebuilt; only remnants of destroyed original trabeculae are seen. The normal trabecular bone has been replaced by irregularly structured new bone (fig. 2i). Vessel channels of various diameters are also apparent in high-magnification SEM images (online suppl. fig. 7a, b). Irregularly organized new bone formation is visible on the cortical surface of the scapula (online suppl. fig. 7c). The inner microstructure of the scapulae reveals similar pathological changes. However, in some places, unusual formations were detected (online suppl. fig. 7d). Under greater magnification they consist of tiny channels and of bunches of collagenous fibers (online suppl. fig. 7e). They are atypical, and not part of the normal structure of osseous tissue, representing new bone formations and perhaps distant local metastatic calcifications.

\section{Case 3: EB 284A}

The specimen consists of the almost complete skeletal remains of an adult individual. The general preservation of the skeleton is moderately good, although there has been some postmortem damage (online suppl. fig. 8). The sexual traits of the bones are feminine. According to the ossification of the cranial sutures and the inner structure of the humerus and femur, the age at death of this female can be estimated at $45-49$ years. The skeletal remains exhibit distinctive patterns of pathological lesions, which include lesions of the skull (except the maxilla and mandible), vertebrae, ribs, both scapulae, right humerus, hip bones, sacrum and both femora (online suppl. fig. 8).

Macroscopy and Radiology of Pathological Changes

The morphology and the anatomical distribution of the lesions are described below, broken down to the specific bone in question. There is a localized fine porosity manifest in the skull on the endocranial surface along the frontal crest $(15 \times 5 \mathrm{~mm})$. The right parietal bone also exhibits a circular porotic lesion (diameter: $20 \mathrm{~mm}$ ) surrounded by slight periosteal reaction.

Most vertebrae, mainly in the thoracic and lumbar regions, show pitting on their anterior and lateral surfaces, and scattered deposits of fine porotic new bone formation. They also show deposits of new bone in the trabecular part, visible at postmortem brakes: deposits of finegrained bone fill the space between the normal bone trabeculae or obliterate the normal internal structure entirely (fig. 3a). In the ribs, the predominant pathological changes are multiple lytic lesions perforating the cortical bone. However, there is some proliferative bone, often located very close to the lytic lesions (fig. 3b; online suppl. fig. $9 \mathrm{~b}, \mathrm{c}$ ). Due to postmortem damage, the inner structure of the ribs is visible in some cases (fig. $3 c$; online suppl. fig. 9a-d). The original spongy bone has almost completely been replaced by sclerotic new bone (fig. 3c; online suppl. fig. 9a). Both scapulae exhibit irregular, reactive bone in some locations, more marked on the left than the right side. Large areas of new bone deposits are situated in the supero- and lateromedial surfaces of the left scapula, mainly surrounding the glenoid fossa (fig. 3d), in the subscapular fossa (online suppl. fig. 9e), at the base of the acromial process and on the spine of scapula. Obliteration of the normal cancellous bone structure by sclerotic new bone is also seen at the site of the broken

Fig. 3. Pathological changes of skeleton EB 284A. a Complete obliteration of normal bone trabeculae (lumbar vertebra). b Proliferative lesions closely related to the lytic lesions of a rib. c Fine trabecular new bone filling the spaces in a rib. $\mathbf{d}$ New bone deposits surrounding the glenoid fossa of the left scapula (ventral surface). e Replacement of normal spongy bone by nuclei of densely packed new bone (right pubic bone). f Multiple heterogeneous outgrowths on the lateral surface of the left iliac wing. $\mathbf{g}$ Endosteal deposits of reactive fiber bone formations (left femur). h, i Axial and MPR CT images of the vertebra, showing focal sclerotic lesions and radiolucent areas. $\mathbf{j}$ SEM image of a rib revealing proliferating new bone with an irregular structure both on the periosteal (1) and endosteal (3) surfaces. 2 = Original cortical layer. $\mathbf{k}$ Necrotic original trabeculae (1) and fine trabecular new bone filling the spaces (2). SEM image of a sclerotic nucleus (pubic bone).

(For figure see next page.)
Merczi et al. 


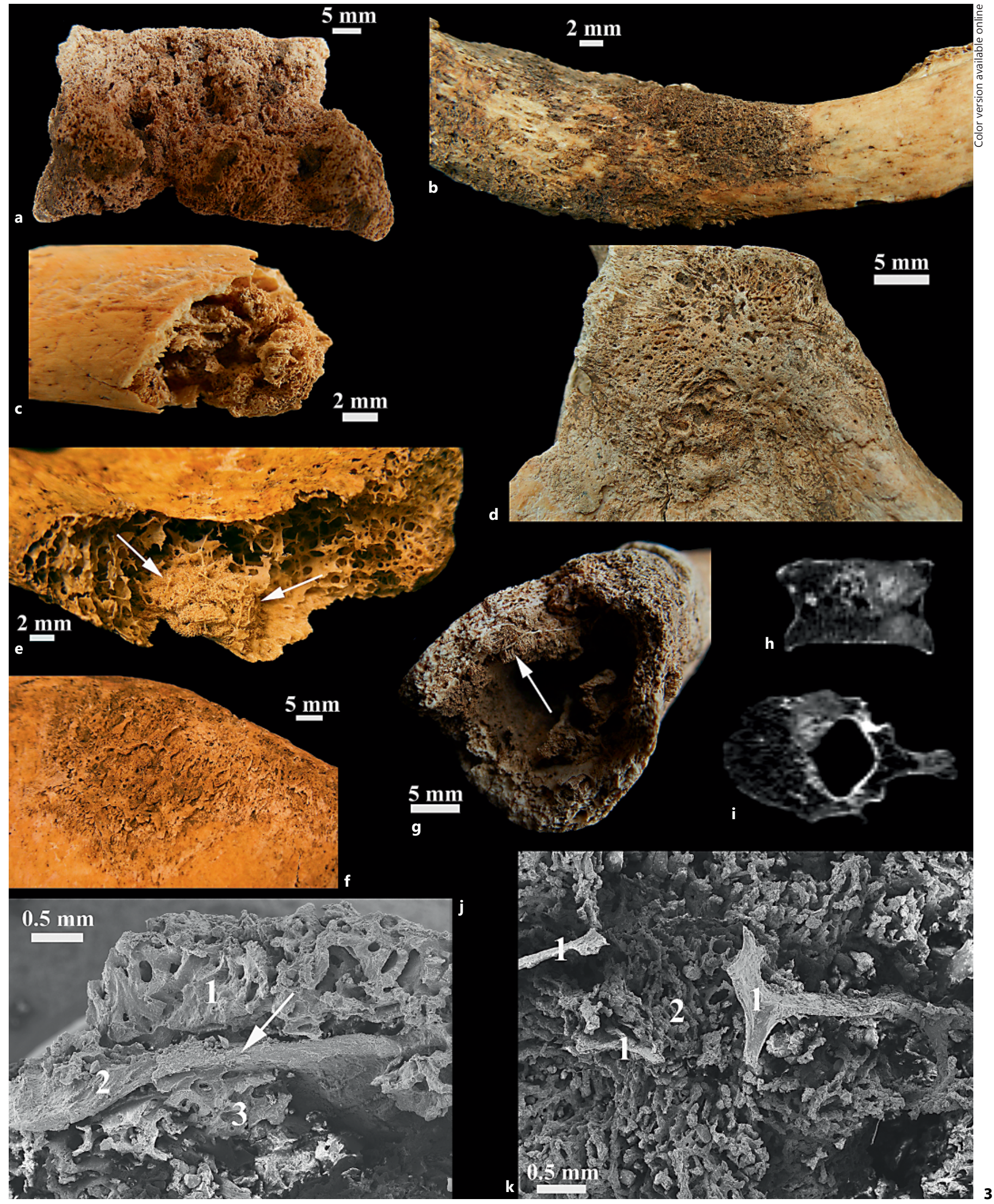

Skeletal Metastatic Carcinomas from the

Pathobiology 2014;81:100-11

107 Roman Period in Hungary 
left coracoid process (online suppl. fig. 9f). The medial surface of the right scapula also reveals massive periosteal new bone formation (online suppl. fig. $9 \mathrm{~g}$ ).

The left humerus is well preserved; there are no pathological alterations on the external surfaces. However, in the greater tubercle of the right humerus, the spongy bone reveals a globular sclerotic focus (diameter: $8 \mathrm{~mm}$ ). Both pelvic bones are affected mainly by heterogeneous osteoblastic lesions, greater in extent on the right than on the left. The upper portion of the right medial surface near the anterior superior iliac spine shows parallel, organized, nodular new bone formations (online suppl. fig. 10a, b). The thickness of the newly formed bone is $1-2 \mathrm{~mm}$. The cortical layer is extremely porotic $(2-5 \mathrm{~mm}$ in diameter) in the vicinity of the arcuate line. Porosity is often associated with fine, sponge-like new bone. Widespread sclerotic lesions are clearly visible inside the fragmentary pelvic bones, and the main feature is the replacement of normal spongy bone by nuclei of densely packed new bone (fig. 3e). The lateral surface of the left iliac wing displays multiple heterogeneous outgrowths in the proximity of the anterior superior iliac spine, inferior to the iliac crest and posterior to the greater sciatic notch (fig. 3f). The appearance of the new bone formations is very different. There are flat porous lesions of irregular shape, spongelike and smooth surfaces, and rounded neoformation. Both the original cortical surface and the surface of the new bone are highly porous. The diameter of the pores varies between 1 and $5 \mathrm{~mm}$.

The anterior surface of the fragmented sacrum shows surface pitting. In the body of the first sacral segment there are small sclerotic foci. The left femur displays deposits of reactive woven bone formations both on the endosteal and periosteal surfaces (fig. 3g; online suppl. fig. 10c). The deposits are most pronounced in the subtrochanteric area. General pitting of the cortex is also apparent. Sclerotic areas of cancellous bone can also be seen in the region of the femoral neck. Similar changes can be detected on the right femur.

The CT images of the examined bones represent a number of different types of pathological change, as well as multiplex osteoblastic and osteolytic lesions. The axial and MPR CT images of a vertebra show focal sclerotic lesions and radiolucent areas (fig. $3 \mathrm{~h}, \mathrm{i}$ ).

\section{Scanning Electron Microscopy}

Three samples (from the rib, pubic bone and iliac bone) were taken for SEM analysis. The SEM pictures of the rib reveal proliferating new bone with an irregular structure both on the endosteal and periosteal surfaces (fig. 3j; online suppl. fig. 10d). For SEM analysis, a spongy bone sample from a sclerotic nucleus of pubic bone was taken. Partly damaged and completely destroyed original trabeculae, and fine trabecular new bone filling the spaces between the trabeculae, can be recognized (fig. 3k; online suppl. fig. 11a). In some places, the invasion of the new bone can be clearly seen: the necrotic trabeculae are encircled by unorganized, newly built bone (online suppl. fig. 11b). Resorption of the original trabeculae can be clearly seen in a detailed SEM picture of the iliac bone sample (online suppl. fig. 10e).

\section{Diagnosis}

The age at death of the affected individuals was 40 50 years in all 3 cases ( 2 males and 1 female). The anatomical distribution of the detected alterations shows a great similarity among them. The pelvic bones, the spine and the femora are affected in all specimens. In the 2 Esztergom cases (EB 262 and EB 284A), the skull, the ribs and both scapulae are also affected, but these parts of the skeleton of the G 1287 individual are absent due to a postmortem cause. The pathological changes are macroscopically similar: mainly osteoblastic lesions were seen, but osteolytic alterations were also observed.

The radiological examination supported the macroscopic observations, namely the sclerotic nature of the alterations in 2 cases (EB 262 and G 1287) and the mixed nature of the lesions in 1 case (EB 284A). Based on the SEM study, besides osteoblastic changes, osteolysis is also present in all 3 cases. The anatomical distribution of the lesions, their macroscopic and radiographic characteristics, as well as details revealed by scanning electron microscopy favor a diagnosis of metastatic carcinoma. The age at death of the affected individuals accords with this diagnosis.

It is worth mentioning that in case $\mathrm{G} 1287$, the diagnosis is only hypothetical, because severe postmortem erosions are present. The alterations might also be the result of nonspecific infectious diseases.

\section{Differential Diagnosis}

In paleopathology there is a certain level of difficulty in differentiating between secondary tumors like metastatic carcinoma and other pathological abnormalities. The mixed nature of the detected lesions excludes diseases causing purely or mainly lytic bony alterations, 
such as multiple myeloma, histiocytosis $\mathrm{X}$, or lytic types of secondary tumors $[15,43,46]$. Consideration should be given to a wide range of bone conditions which may result in bony deposits and overall increase in bone quantity, such as osteopetrosis, sclerosteosis, endosteal hyperostosis, pachydermoperiostosis, osteopoikilosis, melorheostosis, osteomesopyknosis, myelofibrosis, tuberous sclerosis, hypervitaminosis $\mathrm{A}$, fluorosis and hypoparathyroidism $[14,47]$. However, the radiographic picture, the morphology and localization of the lesions, the presence of external bony deposition, and the age of the affected individuals do not support these diagnostic possibilities.

Bone overgrowth in elderly people, however, could be due to Paget's disease (osteitis deformans). This disease is a chronic skeletal disorder characterized by abnormal and excessive remodeling of bone. Three major phases are recognized: (1) the lytic phase (incipient active), in which osteoclastic resorption predominates; (2) the mixed phase (active), in which there are both osteoclastic and osteoblastic hyperplasia with predominant osteoblastic activity; and, finally, (3) the blastic phase (late inactive), in which osteoblastic activity gradually declines. The anatomic distribution of Paget's disease is usually asymmetric and most commonly affects the pelvis, lumbar spine, sacrum, femur and cranium. There is a preference for the lower extremities and a tendency for rightsided alterations. On the basis of the mixed and osteoblastic nature of the alterations detected in the cases examined, the diagnosis of Paget's disease could not be excluded. However, the symmetrical anatomical distribution of the pathological alterations does not support this diagnosis $[43,48-50]$.

Several primary bone tumors such as osteosarcoma or osteogenic sarcoma are able to mimic the response induced by metastasizing carcinoma. These malignant bone-forming tumors can arise on the cortical surface of bones, constituting one of the most frequent bone neoplasms. The aggressiveness of the tumor may create a distinct pattern in the bone, ranging from purely osteolytic or osteoblastic forms to those with a mixed response, which are more typical $[43,51,52]$. The extracortical portion of the tumor may exhibit a radiant alignment of tumor bone, the so-called 'sunburst' appearance. This tumor occurs most often in adolescents or young adults, especially males, and this primary tumor is more frequent in the long bones, particularly in the distal part of the femur and in the proximal parts of the tibia and humerus $[43,52]$. The age of the affected individuals, the localization of the lesions (predominantly in the axial skeleton

Skeletal Metastatic Carcinomas from the Roman Period in Hungary and skull), and the radiographic pictures are incompatible with a case of osteosarcoma.

In the differential diagnosis of metastatic carcinoma it is also important to consider certain types of specific and nonspecific infections, such as tuberculosis and osteomyelitis $[43,52]$. The diagnosis of tuberculosis in paleopathology traditionally focuses on the search for vertebral lesions and joint destructions, particularly of the hip and knee. In bone tuberculosis there is a dominance of destructive processes over proliferative reactions $[43,52]$. In the skeletons studied, no joint involvement was observed, and the vertebral lesions do not suggest tuberculosis. Moreover, the mainly osteoblastic nature of the detected lesions does not suggest a tuberculous process.

Osteomyelitis is a bone infection with a primary incidence in the medullary cavity of long bones. Additionally, it may cause an inflammation in the periosteum (periostitis) or in the endosteum (osteitis). The lesions involve a mixed pattern with destructive and remodulative processes. The most conspicuous traits include the formation of sequestra and draining cloacae $[43,52]$. The absence of these symptoms ruled out a diagnosis of osteomyelitis.

\section{Discussion and Conclusion}

Although different types of neoplasms vary regarding their metastatic sites, the most commonly affected areas are probably the spine and sacrum, proximal femoral epiphysis and metaphysis, sternum, ribs, skull, pelvis and proximal humerus with their hematopoietic function as marrow reservoirs. Skeletal metastasis distal to the elbows and knees is apparently rare and does not occur in the fibulae $[15,43,53]$. This evidence supports the hypothesis that the lesions described above are the consequence of some kind of metastatic cancer.

The identification of specific tumor types in bone often depends on careful histological examination of softtissue components and/or clinical tests available to modern pathologists. This information will not usually be available to those engaged in the differential diagnosis of tumors in archeological human remains, and a specific diagnosis of tumor type will not always be plausible. This is particularly the case with metastatic carcinomas affecting bone, which often have very similar skeletal manifestations regardless of the primary site of the tumor $[54,55]$.

Traditionally, bone metastases have been thought of as either osteolytic or osteoblastic, with entirely different 
factors being responsible for each. From this viewpoint, osteolytic metastases are believed to be caused by osteoclast-activating factors which are released by tumor cells in the bone microenvironment. Osteoblastic metastases, conversely, are believed to be caused by the cancer-cell production of factors that stimulate osteoblast proliferation, differentiation and bone formation. Osteolytic and osteoblastic lesions are two extremes - morphological analysis of recent cancer patients has revealed that in most cases with skeletal metastases there are both osteolytic and osteoblastic elements [56].

Tumors arising in the breast and prostate gland are particularly likely to disseminate to bone $-70 \%$ of patients who die from these cancers present evidence of skeletal deposits at postmortem examinations. Carcinomas of the thyroid, kidney and bronchi also commonly give rise to bone metastases, with an incidence at autopsy of $30-40 \%$. Tumors of the gastrointestinal tract, on the other hand, rarely produce bone metastases, and are seen in only about $5 \%$ of patients dying from these malignancies $[53,56]$.

Osteolytic metastases commonly arise from carcinomas of the lung, kidney and thyroid and from lymphoma. Osteoblastic metastases are most often associated with prostatic and breast carcinomas, but also with Hodgkin's lymphoma and carcinoids. Mixed lesions can be associated with any type of metastatic tumor, but are most common in carcinomas of the lung and breast. Periosteal reactions are highly unusual in metastatic disease except in prostatic carcinomas, breast carcinomas and gastrointestinal malignancies [57].
Differentiation of metastatic lesions in archeological human skeletal remains is likely to be difficult, if not impossible, but the abovementioned differences could be helpful in our cases. The mixed nature of the lesions at both macroscopic and microscopic levels, the radiological picture of the detected lesions and the sex of the individual in case EB 284A (mature, female) suggest breast cancer as the primary focus, but other malignancies such as thyroidal carcinoma could not be excluded as the prime affection.

In cases EB 262 and G 1287 (mature, male) the lesions are predominantly osteoblastic; however, some osteolytic alterations are also visible. A precise diagnosis is not possible, but a diagnostic option - based on the mostly osteoblastic nature of the alterations, localization of the lesions, and the sex of the affected individuals - is primary carcinoma of the prostate gland with skeletal metastases.

In view of the scarcity of cancer metastases - particularly those with blastic components - that have been diagnosed in archeological specimens in general, it is important to report all new cases which are discovered. Identification of all examples of cancer in antiquity represents an important contribution to paleopathology in light of the increasing clinical, epidemiological and demographic importance of this disease today.

\section{Acknowledgments}

Current research is supported by Hungarian National Scientific Research Foundation (OTKA) project No. NN 78696 and 100956, for which the authors are grateful.

\section{References}

1 Capasso LL: Antiquity of cancer. Int J Cancer 2005;113:2-13.

2 Schultz M: Zur Morbidität neolithischer Populationen: ein Beitrag zur Paläopathologie. Homo 1989;40:81-98.

3 Brothwell D: Tumours and tumour-like processes; in Pinhasi R, Mays S (eds): Advances in Human Palaeopathology. Chichester, John Wiley \& Sons, 2008, pp 253-281.

$\checkmark 4$ Halperin EC: Paleo-oncology: the role of ancient remains in the study of cancer. Perspect Biol Med 2004;47:1-14.

5 Fornaciari G, Giuffra V: Soft tissue tumors in palaeopathology: a review. Pathobiology 2012;79:257-267.

6 Kuhn G, Schultz M, Müller R, Rühli FJ: Diagnostic value of micro-CT in comparison with histology in the qualitative assessment of historical human postcranial bone pathologies. Homo 2007;58:97-115.
7 Schmidt-Schultz TH, Schultz M: Bone protects proteins over thousands of years: extraction, analysis, and interpretation of extracellular matrix proteins in archeological skeletal remains. Am J Phys Anthropol 2004;123:3039.

8 Schultz M, Parzinger H, Posdnjakov DV, Chikisheva TA, Schmidt-Schultz TH: Oldest known case of metastasizing prostate carcinoma diagnosed in the skeleton of a 2,700-year-old Scythian King from Arzhan (Siberia, Russia). Int J Cancer 2007;121:25912595.

9 Tóth GA, Puskás T, Buda BL: Diagnózis: ezer évvel később (Radiológiai módszerek a paleopathologiában). Orvostud Ért 2008;81:232262.

10 Pálfi G: The occurrence of bone tumors in the anthropological remains belonging to the Székkutas-Kápolnadülő cemetery (Hungary) of the Late Avar period. Acta Biol Szeged 1989;35:207-220.

11 Strouhal E, Vyhnánek L, Horáčková L, Benešová L, Němečková A: Malignant tumours affecting the people from the ossuary at Krrtiny (Czech Republic). J Paleopathol 1996;8:5-24.

12 Šefč́áková A, Strouhal E, Němečková A, Thurzo M, Staššíková-Štukovská D: Case of metastatic carcinoma from end of the 8thearly 9th century Slovakia. Am J Phys Anthropol 2001;116:216-229.

13 Marcsik A, Szathmáry L, Finnegan M: Multiple myeloma and metastatic skeletal lesions in osteoarchaeology samples. J Paleopathol 2002;14:77-86.

14 Wakely J, Anderson T, Carter A: A multidisciplinarian case study of prostatic(?) carcinoma from mediaeval Canterbury. J Archaeol Sci 1995;22:469-477. 
15 Wasterlain SN, Ascenso BF, Silva AM: Skeletal metastatic carcinoma: a case from 15th20th century Coimbra, Portugal. Int J Osteoarchaeol 2011;21:336-346.

- 16 Minozzi S, Catalano P, Caldarini C, Fornaciari G: Palaeopathology of human remains from the Roman Imperial Age. Pathobiology 2012;79:268-283.

$\checkmark 17$ Schultz M: Nature and frequency of bony tumors in prehistoric and historic populations. Vivo 1992;6:439-441.

18 Ricci R, Lama R, di Tota G, Capelli A, Capasso LL: Some considerations about the incidence of neoplasms in the human history. J Paleopathol 1995;7:5-11.

-19 Zink AR, Rohrbach H, Szeimies U, Hagedorn HG, Haas CJ, Weyss C, Bachmeier B, Nerlich AG: Malignant tumors in an ancient Egyptian population. Anticancer Res 1999;19:42734277.

20 Strouhal E: Malignant tumours in past populations in Middle Europe; in la Verghetta M, Capasso LL (eds): Proceeding of the VIIIth European Meeting of the Paleopathology Association. Teramo, Edigrafical, 2000, pp 265 272.

21 Nerlich AG, Rohrbach H, Bachmeier B, Zink AR: Malignant tumors in two ancient populations: an approach to historical tumor epidemiology. Oncol Rep 2006;16:197-202.

22 Roumelis N: The palaeopathology of Kirchberg: evidence of deficiency, inflammatory and tumorous disease in a medieval rural population in Hessia, Germany. Thesis and Papers in Osteoarchaeology, No 3. Stockholm, University of Stockholm, 2007.

23 Józsa L, Fóthi E: Juxtacortical osteosarcoma on tibia and fibula from a medieval cemetery of Budapest. J Paleopathol 2003;15:23-31.

24 Farkas LG, Józsa L, Paja L, Molnár J: Bone forming tumors on skeletons from a medieval Hungarian cemetery (Bátmonostor). Paleopathol Newsl 2007;140:14-22.

25 Nemeskéri J, Harsányi L: Die Bedeutung paläopathologischer Untersuchungen für die historische Anthropologie. Homo 1959; 10: 203-226.

26 Éry K: Reconstruction of the tenth century population of Sárbogárd on the basis of archeological and anthropological data. Alba Regia 1967-1968;8-9:93-147.

27 Bartucz L: Paleopathologia III: A prehistorikus trepanációk és orvostörténeti vonatkozású sírleletek. Budapest, Medicina Könyvkiadó, 1966.

28 Farkas G, Marcsik A: Palëopathologische Fälle in der awarenzeitlichen Serie von BackaTopola SFR Jugoslavien. EAZ 1979;20:15-33.

29 Marcsik A, Vékony L: Pathological deformations of bones from the 18th century, BackaTopola, Jugoslavia; in Haneveld GT, Perizonius WRK (eds): Proceedings of the IVth European Meeting of the Paleopathology Association. Utrecht, Elinkwijk BV, 1982, pp 126-130.
30 Pap I: Anthropological investigation of the Arpadian Age population of Szabolcs-Petöfi utca. Anthropol Hung 1980-1981;17:65-107.

31 Molnár E, Marcsik A, Bereczki Z, SchmidtSchultz TH, Schultz M, Pálfi G: Malignant tumors in osteoarchaeological samples from Hungary. Acta Biol Szeged 2009;53:117-124.

32 Molnár E, Marcsik A, Schultz M, Pálfi G: Osteoplasticus metastasis nyomai egy $10-11$. századi csontvázleleten (Traces of an osteoplastic metastasis in a 10 - to 11 th-century skeleton). Anthrop Közl 2011;52:33-40.

33 Józsa L, Fóthi E: Juxtacorticalis osteosarcoma középkori vázleleten. Magy Onkol 2002;46: 271-276.

34 Kelemen MH: Solva castellum; in Visy Z (ed): The Roman Army in Pannonia: An Archaeological Guide of the Ripa Pannonica. Budapest, Teleki László Foundation, 2003, pp 8687.

35 Zsidi P: Kutatások az aquincumi polgárvárostól keletre lévő területen (Research in the territory east of the Aquincum civil town); in Zsidi P (ed): Aquincumi Füzetek 7. - A BTM Aquincumi Múzeumának ásatásai és leletmentései 2000-ben. Budapest, Budapesti Történeti Múzeum, 2001, pp 76-84.

36 Lassányi G: Feltárások az egykori Óbudai Gázgyár területén (Excavations in the area of the former Obuda gas factory); in Zsidi P, Vámos P (eds): Aquincumi Füzetek 16. - A Budapesti Történeti Múzeum ásatásai 2009-ben. Budapest, Budapesti Történeti Múzeum, 2010, pp 25-38

37 Lassányi G: Ásatások az egykori Óbudai Gázgyár területén 2010-ben (Excavations in the area of the former Óbuda gas factory in 2010); in Zsidi P, Vámos P (eds): Aquincumi Füzetek 17. - A Budapesti Történeti Múzeum ásatásai 2010-ben. Budapest, Budapesti Történeti Múzeum, 2011, pp 36-51.

38 Kelemen M: Solva: Esztergom későrómai temetői. Libelli Archaeologici Ser Nov, No III. Budapest, Magyar Nemzeti Múzeum, 2008.

39 Éry K, Kralovánszky A, Nemeskéri J: Történeti népességek rekonstrukciójának reprezentációja (A representative reconstruction of a historical population). Anthropol Közl 1963; 7:41-90.

40 Acsádi G, Nemeskéri J: History of Human Life Span and Mortality. Budapest, Akadémiai Kiadó, 1970.

41 Nemeskéri J, Harsányi L, Acsádi G: Methoden zur Diagnose des Lebensalters von Skelettfunden. Anthropol Anz 1960;24:70-95.

42 Isçan MY, Loth SR, Wright RK: Age estimation from the rib by phase analysis: white males. J Forensic Sci 1984;29:1094-1104.
43 Ortner DJ: Identification of Pathological Conditions in Human Skeletal Remains. New York, Academic Press, 2003.

44 Merczi M: A castellumtemető (Esztergom Bánomi dűlő) népességének embertani vizsgálata; in Kelemen MH: Solva: Esztergom későrómai temetői. Libelli Archaeologici Ser Nov, No III. Budapest, Magyar Nemzeti Múzeum, 2008, pp 401-478.

45 Merczi M: Verletzungen an spätrömischen Schädeln aus Nordost-Pannonien; in Schalles HJ, Busch AW (eds): Waffen in Aktion: Akten der 16. Internationalen Roman Military Equipment Conference (ROMEC), Xanten, 13.-16. Juni 2007. Xantener Berichte, vol 16. Mainz, Philipp von Zabern, 2009, pp 165 182.

46 Marks MK, Hamilton MD: Metastatic carcinoma: paleopathology and differential diagnosis. Int J Osteoarcheol 2007;17:217-234.

-47 Anderson T, Wakely J, Carter A: Medieval example of metastatic carcinoma: a dry bone, radiological, and SEM study. Am J Phys Anthropol 1992;89:309-323.

48 Wade AD, Holdsworth DV, Garvin GJ: CT and micro-CT analysis of a case of Paget's disease (osteitis deformans) in the Grant skeletal collection. Int J Osteoarcheol 2011;21:127135

49 Smith SE, Murphey MD, Motamedi K, Mulligan ME, Resnik CS, Gannon FH: From the archives of the AFIP: radiologic spectrum of Paget disease of bone and its complications with pathologic correlation. Radiographics 2002;22:1191-1216.

50 Theodorou DJ, Theodorou SJ, Kakitsubata Y: Imaging of Paget disease of bone and its musculoskeletal complications: review. AJR Am J Roentgenol 2011;196(6 suppl):S64-S75.

51 Resnick D, Kransdorf MJ: Skeletal metastasis in Resnick D, Kransdorf MJ (eds): Bone and Joint Imaging, ed 3. Philadelphia, Elsevier Saunders, 2005, pp 1245-1264.

52 Assis S, Codinha S: Metastatic carcinoma in a 14th-19th century skeleton from Constância (Portugal). Int J Osteoarchaeol 2010;20:603620

53 Rubens RD, Mundy GR: Cancer and the Skeleton. London, Martin Dunitz, 2000.

54 Dorfman HD, Czerniak B: Metastatic tumors in bone; in Dorfman HD, Czerniak B (eds): Bone Tumors. St Louis, Mosby, 1998, pp 1009-1040.

55 Greenspan A, Remagen G: Metastases; in Greenspan A, Remagen G (eds): Differential Diagnoses of Tumors and Tumor-Like Lesions of Bones and Joints. Philadelphia, Lippincott Williams \& Wilkins, 1998, pp 367387.

56 Mundy GR: Metastasis to bone: causes, consequences and therapeutic opportunities. Nat Rev Cancer 2002;2:584-593.

57 Burgener FA, Kormano M, Pudas T: Differential Diagnosis in Conventional Radiology. Stuttgart, Thieme, 2008.
Skeletal Metastatic Carcinomas from the Roman Period in Hungary
Pathobiology 2014;81:100-111 DOI: $10.1159 / 000357435$ 